\title{
Spatial and temporal partitioning and tree preference in California woodland
}

\section{ants}

Dylan MacArthur-Waltz, Rebecca Nelson, Gail Lee, and Deborah M. Gordon*

Affiliations: Stanford University, Department of Biology, 371 Serra Mall, Stanford, CA 94305.

Correspondence: Dr. Deborah Gordon, dmgordon@,stanford.edu, (650) 725-6364.

Abstract: Spatial and temporal partitioning of habitat may facilitate diversity and have important impacts on ant communities. To investigate niche overlap in an ant community in a northern California oak

11 woodland, we observed ant foraging on trees in 4 seasonal surveys, each lasting 2 weeks, in a 9.5-hectare

12 plot over the course of a year. Foraging activity in all 5 observed ant species differed by season, time of

13 day, and/or the genera of trees used. Of the 3 ant species most frequently observed, Camponotus

14 semitestaceus was most active during spring and summer nights, Formica moki was most active during

15 spring and summer days, and Prenolepis imparis was most active during both day and night of fall and

16 winter. All ant species preferred native trees to exotic trees and preferred evergreen trees to deciduous

17 trees. Our results suggest that native evergreen oaks such as Quercus agrifolia, currently threatened by

18 sudden oak death (Phytophthora ramorum), may be important for supporting ant biodiversity.

\section{Acknowledgements}

21 Authors DM, RN and DMG contributed equally to the writing of this manuscript. This project was

22 financially supported by a Small Grant awarded by the Stanford University Office of Undergraduate

23 Advising and Research. We gratefully acknowledge Angela Gu, Duncan Coleman, Eleanor Glockner,

24 Julie Fukunaga, Katie Lan, and Miranda Vogt for many hours of field work assistance. We thank Rodolfo

25 Dirzo, Daniel Friedman and Maria Wojakowski for providing advice and assistance with statistical 
analysis. Leander D.L. Anderegg, Talia Borofsky, Kaleda Denton, and Tyler McFadden provided helpful

Keywords: Niche Partitioning, Foraging, Trees, Native/Non-Native, Prenolepis imparis

\section{Introduction}

A central question in community ecology is how communities preserve diversity despite interspecific competition (1-3). Ant communities are ideal systems for studying coexistence because they

35 are diverse, may include many similar species (which are theoretically more likely to compete strongly),

36 and greatly influence ecosystem function (4-6). Many ant species have strong associations with particular

37 host plant species (6-8), and this may reduce competition among coexisting ant species.

49 In our study system, five common native ant species (Camponotus semitestaceus,

50 Formica moki, Liometopum occidentale, Prenolepis imparis, and Tapinoma sessile) coexist in a mixed 
51 native-exotic woodland in northern California in a Mediterranean climate with wet winters and dry

52 summers. All five ant species forage on trees and all apparently forage on aphid honeydew (24-26).

53 Our study site has a mixture of native and exotic tree species planted over the last 200 years;

54 previously the site was a mixture of grassland and oak savanna (27). Typical native tree species include

55 oaks: Quercus agrifolia, Q. lobata, and Q. douglasii; typical exotic species include Eucalyptus

56 spp., Olea europaea, and Schinus molle. Oaks play an important role in maintaining biodiversity in

57 California forests (28). Quercus agrifolia is vulnerable to sudden oak death (Phytophthora ramorum), a

58 pathogen of emerging concern in northern California (28). Disturbances such as sudden oak death may

59 negatively affect ant community dynamics.

60 We conducted seasonal surveys during both day and night, across a variety of tree genera, to

61 examine niche partitioning in an urbanized, northern Californian ant community. We asked the following

62 questions:

63 1: Do ant species differ in foraging activity across seasons?

64 2: Do ant species differ in foraging activity between day and night?

65 3: Do ant species differ in their use of tree genera, native versus exotic trees, and deciduous versus

66 evergreen trees for foraging?

68 Methods

69 Survey Region

70 We surveyed ant activity on and around tree trunks in a 9.53 ha region of the wooded Arboretum

71 on the Stanford University campus. The survey region consisted of mixed oak-exotic woodland without

72 significant brushy understory. Trees were identified using maps from the Stanford Maps and Records

73 office (340 Bonair Siding Rd., Stanford, CA), which included GPS coordinates and species for each tree.

74 Common ant species at the site included Camponotus semitestaceus, Formica moki, Liometopum

75 occidentale, Prenolepis imparis, and Tapinoma sessile. We did not observe any other ant species at our

76 study site in significant abundance (i.e., inhabiting $>10$ trees in any season). We observed Linepithema 
77 humile during spring, summer, and fall surveys in $<10$ trees on the northwestern edge of the survey

78 region.

Four seasonal surveys, each lasting up to 2 weeks, were conducted in 2016-2017 from 29-July2016 - 8-August-2016 (Summer); 12-November-2016 - 13-November-2016 (Fall); 22-February-2017 -

81 26-February-2017 (Winter); and 12-May-2017 - 19-May-2017 (Spring). We surveyed each of

82 approximately 870 trees twice during each season, once during the day and once at night, for a total of

837008 individual tree observations. We did not survey on rainy days as ants were not active. We did not

84 survey in the hour before or after sunrise and sunset. We eliminated trees that died between surveys from

85 the sample set. For about 20 trees, growth around the base was too dense to allow observation, and those

86 trees were not included in our final analysis.

87 Observations were made by the authors and six research assistants. Ants were identified to species

88 in the field or after observations using specimens collected at the time of observation. During each survey,

89 we observed the bottom $2 \mathrm{~m}$ of the tree trunk and a $1 \mathrm{~m}$ radius around the base of the tree. We recorded all

90 ant species present on the trunk and the base, and we estimated their abundance as follows: low

91 abundance $=1-5$, medium abundance $=6-30$, high abundance $=>30$ individuals. We also recorded the

92 presence of trails of any ant species. A trail was recorded if ants appeared concentrated in a line on the

93 tree trunk (as opposed to scattered randomly around the trunk) or if ants moving in opposite directions

94 touched antennae in passing. Observations lasted approximately 30 seconds - 1 minute per tree. All data

95 are available for download (29).

96 We observed but did not map the presence of nests within the survey region. We observed about

9710 nests of Liometopum occidentale only in Quercus agrifolia. We observed several Prenolepis imparis

98 nests on the ground, greater than 10 Camponotus semitestaceus nests on the ground and 2 Formica moki

99 nests on the ground. We did not find any Tapinoma sessile nests.

100

101 Data Analysis 
All statistical tests were performed in RStudio Version 1.1.383. We compared ant presence across seasons, day/night, tree genera, and ant species using Kruskal-Wallis rank sum tests. We then performed a

104 second series of Kruskal-Wallis tests with the same factors and ant abundance as the response variable, 105 using the median values of our bins of ant abundance in each category (1-5 ants $\cong 3,6-29$ ants $\cong 18,30+$

106 ants $\cong 100$ ). Because the results of the presence/absence model and the abundance model were very

107 similar (Table S1), we then used only the presence/absence model for species-specific analysis.

108 Season*Day_Night interaction terms were significant for the majority of species observed, so we

109 combined Season (four levels) and Day_Night (two levels) into a single factor with eight levels (for

110 example, one level was Summer Day). We ran post hoc Dunn tests on this combined variable for each ant

111 species. We adjusted all p-values using the Benjamini-Hochberg procedure.

112 For each of the 5 most common ant species: Camponotus semitestaceus,

113 Formica moki, Liometopum occidentale, Prenolepis imparis, and Tapinoma sessile, we performed a

114 Kruskal-Walls tests on season, day/night, and genus individually. We used post hoc Dunn tests to

115 determine the effect of season, day/night, and tree genus preference on ant presence for each individual 116 species.

117 For each survey, we calculated the percentage of all deciduous, evergreen, native, and non-native

118 trees that were occupied by any species of ant. We asked whether all species of ants preferentially used

119 deciduous or evergreen trees, and native or exotic trees, using paired t-tests.

\section{Results}

\section{Question 1: Do ant species differ in foraging activity across seasons?}

The species present depended on season (Kruskal-Wallis, $\chi^{2}=265.6, p<2.2 \times 10^{-16}$ ). Camponotus

124 semitestaceus was observed most frequently during the spring and summer. Formica moki was observed 125 most frequently during the spring and summer. Liometopum occidentale was observed most frequently 126 during the summer. Prenolepis imparis was observed most frequently in the fall, slightly less frequently 
127 in the winter, less in the spring, and rarely in the summer. Tapinoma sessile was observed most frequently

128 during the summer (See Figure 1 for Dunn post hoc results).

\section{Question 2: Do ant species differ in foraging activity between day and night?}

Most species differed in activity between day and night (Kruskal-Wallis, $\chi^{2}=92.0, \mathrm{p}<2.2 \times 10^{-16}$,

132 Table S1), and these day-night differences varied among seasons. Camponotus semitestaceus was

133 significantly more active at night than during the day, and this activity level depended on season

134 (Kruskal-Wallis, $\left.\chi^{2}=1660, \mathrm{p}<2.2 \times 10^{-16}\right)$. C. semitestaceus was most often observed during spring and

135 summer nights and observed less commonly during fall and winter nights (Figure 1A). During all seasons

136 except winter, Formica moki was more active in the day than at night, and this activity level depended on

137 season (Kruskal-Wallis, $\left.\chi^{2}=897.98, \mathrm{p}<2.2 \times 10^{-16}\right) . F$. moki was most often observed on spring and

138 summer days (Figure 1B). Activity in Liometopum occidentale depended both on time of day and season

139 (Kruskal-Wallis, $\chi^{2}=59.646, \mathrm{p}<1.776 \times 10^{-10}$ ). L. occidentale was more active on summer days than any

140 time during fall, winter, and spring (Figure 1C). Prenolepis imparis was more active during the night in

141 winter and spring and more active during the day in fall (Kruskal-Wallis, $\chi^{2}=1483.9, \mathrm{p}<2.2 \times 10^{-16}$,

142 Figure 1D). Activity in T. sessile depended on a time of day/season interaction (Kruskal-Wallis, $\chi^{2}$

$143=19.0, \mathrm{p}=0.0083$, Figure 1E). All post hoc Dunn test results are presented in Figure 1, and Kruskal-

144 Wallis results are presented in Tables S1 and S2.

Figure 1. Normalized ant presence by season and day/night for: (a) Camponotus semitestaceus;

147 (b) Formica moki; (c) Liometopum occidentale; (d) Prenolepis imparis; (e) Tapinoma sessile. Normalized ant

148 presence is the number of trees on which an ant species was present divided by the total number of trees surveyed.

149 Gray bars represent observations for day, and black bars represent observations for night. Letters show significant

150 differences in Dunn tests at the $\mathrm{p}<0.05$ level. 
152 Question 3: Do ant species differ in their use of tree genera, native versus exotic trees, and

153 deciduous versus evergreen trees for foraging?

154 Species differed in their use of tree genera (Kruskal-Wallis, $\chi^{2}=216.0, p<2.2 \times 10^{-16}$ ); this effect

155 was observed in all species except Tapinoma sessile (Kruskal-Wallis test; CS: $\chi^{2}=66.3, \mathrm{p}<2.4 \times 10^{-12} ; \mathrm{FM}$,

$\chi^{2}=54.1, \mathrm{p}<7.0 \times 10^{-10} ;$ LO: $\chi^{2}=63.1, \mathrm{p}<1.0 \times 10^{-11} ;$ PI: $\chi^{2}=182.8, \mathrm{p}<2.2 \times 10^{-16} ;$ TS: $\chi^{2}=5.8, \mathrm{p}=0.44$

157 Figure 3).

Camponotus semitestaceus and Formica moki were relatively uncommon on Olea trees (Figure

2A, 2B), while $P$. imparis used Olea trees more often than any other tree genus (Figure 2D). $C$.

semitestaceus preferred Quercus and Eucalyptus trees over Olea and Schinus trees (Figure 2A). F. moki preferred Cedrus trees and then Quercus (Figure 2C).

Figure 2. Ant presence by tree genus. Normalized ant presence is the number of trees on which an ant species was present divided by the total number of trees surveyed. Letters show significant differences in Dunn tests at the $\mathrm{p}<$ 0.05 level. Only tree genera with at least 50 individuals present in the study area were included separately; all other genera were included as "Other." Panel F shows the proportion of each tree genus present. Quercus (in bold) is the only native genus among the six most abundant tree genera at the site.

174 Figure 3. Normalized ant presence in native versus non-native trees (A) and deciduous versus evergreen trees (B).

175 Normalized ant presence is the number of deciduous, evergreen, native, or non-native trees on which any ant species

176 was present divided by the total number of that type of tree surveyed. *** indicates significance at the $\mathrm{p}<0.001$

177 level. 
Discussion

Our study suggests that niche partitioning is occurring in a mixed oak-exotic woodland ant community along three different axes: season, day/night, and tree genus. While other studies have investigated seasonal partitioning or day/night partitioning separately, our study demonstrates that seasonal and day/night scales may interact to influence partitioning.

Figure 4. Differences in diel and seasonal ant activity among the most abundant ant species in a woodland ant community suggest niche partitioning. Camponotus semitestaceus was most active during spring and summer nights; Formica moki was most active during spring and summer days, and Prenolepis imparis was most active in fall and winter during both day and night. Liometopum occidentale was the second most active species during summer day, summer night, and winter day.

192 Prenolepis imparis foraged all day during fall, winter, and spring, which suggests this species relies on 193 colder temperatures. Other studies have shown temperature-dependent activity in P. imparis; in other

194 locations, $P$. imparis forages nocturnally in warm months and diurnally in cold months $(10,30)$. Formica

195 moki is active only during the day in warmer months, which could indicate a preference for warmer

196 temperatures. By contrast, Camponotus semitestaceus has been observed to be nocturnal regardless of

197 temperature or season (24). As in previous studies $(10,31,32)$, we did not observe strong diel or seasonal 198 activity patterns in Liometopum occidentale and Tapinoma sessile.

All species we observed foraged more frequently on native trees, particularly Quercus species.

200 Some niche partitioning, however, occurred in exotic tree genera: P. imparis foraged frequently on Olea,

201 and L. occidentale foraged most frequently on Cedrus, while other species avoided these two exotic tree 202 genera. All species preferred to forage on evergreen trees independently of their preference for native 203 trees, suggesting the distribution of honeydew resources may differ between evergreen and deciduous 
trees. Quercus agrifolia, a native, evergreen species, was the most common tree at the field site and may play an important role in maintaining ant biodiversity.

moki rarely formed trails (Figure S1) and was usually present in low abundance (Figure S3).

210 L. occidentale frequently formed large foraging trails ( $60 \%$ of observations, Figure $\mathrm{S} 1)$, and foraged in

211 clumped trail networks of around three to five trees, which often included a nest tree.

212 Several of the ant species, including F. moki, L. occidentale, and P. imparis, have been described

213 as dominant based on bait assays $(9,10,17,26,33)$. Though we did not offer baits, we frequently observed

214 these species foraging together, which does not support a dominance-discovery tradeoff (34). The ants we

215 observed were probably foraging on trees for aphid honeydew, a spatially stable food source for which

216 repeated discovery may not be needed. Parr \& Gibb $(2012,35)$ suggest that ant communities that rely on

217 honeydew do not demonstrate dominance-discovery tradeoffs.

218 Further research is needed to explore the degree of dietary overlap for these species and whether

219 the limitation and distribution of honeydew resources influences ant community structure. Preferences for

220 particular tree genera may be driven by differences among tree genera in aphid species composition and

221 honeydew availability. The emerging threat of sudden oak death in Quercus may affect ant communities

222 because these species may be disproportionately important in supporting honeydew-feeding ants. Thermal

223 niche partitioning may have important consequences for coexistence after climate change.

\section{Bibliography:}

226 1. Gause G. The Struggle for Existence. New York: Williams \& Wilkins Company; 1934. 163 p.

227 2. Hardin G. The Competitive Exclusion Principle. Science (80- ). 1960;131(3409):1292-7.

228 3. Finke D, Snyder W. Niche partitioning increases resource exploitation by diverse communities.

229 Science (80- ). 2008;321(5895):1488-90. 
230 4. Houadria M, Salas-Lopez A, Orivel J, Bluthgen N, Menzel F. Dietary and Temporal Niche

231 Differentiation in Tropical Ants - Can They Explain Local Ant Coexistence? Biotropica.

$232 \quad 2015 ; 47(2): 208-17$.

233 5. Kaspari M, O’Donnell S, Kercher JR. Energy, density, and constraints to species richness: Ant

234 assemblages across a productivity gradient. Am Nat. 2000;155(2):280-93.

235 6. Hölldobler B, Wilson EO. The Ants. 1st ed. Berlin: Springer; 1990. 732 p.

236 7. Beattie AJ. The Evolutionary Ecology of Ant-Plant Mutualisms. Cambridge University Press;

237 1985. $196 \mathrm{p}$.

238 8. Rosumek F, Silveira F, de S Neves F, de U Barbosa N, Diniz L, Oki Y, et al. Ants on plants: a

239 meta-analysis of the role of ants as plant biotic defenses. Oecologia. 2009;160(3):537-49.

240 9. Fellers JH. Interference and exploitation in a guild of woodland ants. Ecology. 1987;68(5):1466-

24178.

242 10. Fellers JH. Daily and Seasonal Activity in Woodland Ants. Oecologia [Internet]. 1989;78(1):69-

243 76. Available from: http://www.jstor.org/stable/4218832

244 11. Stuble KL, Rodriguez-Cabal MA, McCormick GL, Jurić I, Dunn RR, Sanders NJ. Tradeoffs, 245 competition, and coexistence in eastern deciduous forest ant communities. Oecologia.

$246 \quad 2013 ; 171(4): 981-92$.

247 12. Albrecht M, Gotelli NJ. Spatial and temporal niche partitioning in grassland ants. Oecologia.

$248 \quad 2001 ; 126(1): 134-41$.

249 13. Carval D, Cotté V, Resmond R, Perrin B, Tixier P. Dominance in a ground-dwelling ant $250 \quad$ community of banana agroecosystem. Ecol Evol. 2016;6(23):8617-31.

251 14. Narendra A, Greiner B, Ribi WA, Zeil J. Light and dark adaptation mechanisms in the compound 252 eyes of Myrmecia ants that occupy discrete temporal niches. J Exp Biol [Internet]. 2016;219(16):2435-42. Available from: http://jeb.biologists.org/lookup/doi/10.1242/jeb.142018

254 15. Bestelmeyer BT. The trade-off between thermal tolerance and behavioural dominance in a 255 subtropical south american ant community. J Anim Ecol. 2000;69(6):998-1009. 
16. Cerda X, Retana J, Cros S, Journal S, May N, Cerda XIM, et al. Thermal Disruption of Transitive

Hierarchies in Mediterranean Ant Communities Published by : British Ecological Society Thermal disruption of transitive hierarchies in Mediterranean ant communities. 1997;66(3):363-74.

17. Wittman SE, Sanders NJ, Ellison AM, Jules ES, Ratchford JS, Gotelli NJ. Species interactions and thermal constraints on ant community structure. Oikos. 2010;119(3):551-9.

18. Stahlschmidt ZR, Johnson D. Moving targets : determinants of nutritional preferences and habitat use in an urban ant community. 2018;1151-8.

19. Vonshak M, Gordon DM. Intermediate disturbance promotes invasive ant abundance. Biol Conserv [Internet]. 2015;186:359-67. Available from:

20. Bluthgen N, Verhaagh M, Goitia W, Jaffe K, Morawetz W, Barthlott W. How plants shape the ant community in the Amazonian rainforest canopy: the key role of extrafloral nectaries and homopteran honeydew. Oecologia. 2000;125(2):229-40.

21. Davidson D, Cook S, Snelling R, Chua T. Explaining the abundance of ants in lowland tropical rainforest canopies. Science (80- ). 2003;300(5621):969-72.

271 22. Styrsky JD, Eubanks MD. Ecological consequences of interactions between ants and honeydewproducing insects. Proc R Soc B Biol Sci. 2007;274(1607):151-64.

273 23. Southwood TRE, Moran VC, Kennedy CEJ. The Richness, Abundance and Biomass of the Arthropod Communities on Trees. J Anim Ecol. 1982;51(2):635-49.

275 24. Gano KA, Rogers LE. Colony density and activity times of the ant Camponotus semitestaceus

278 25. Holway DA. Competitive Mechanisms Underlying the Displacement of Native Ants by the Invasive Argentine Ant. Ecology [Internet]. 1999;80(1):238-51. Available from:

281 26. Lynch JF, Balinsky EC, Vail SG. Foraging patterns in three sympatric forest ant species, 
Prenolepis imparis, Paratrechina melanderi and Aphaenogaster rudis (Hymenoptera: Formicidae). Ecol Entomol. 1980;5(4):353-71.

284 27. Cain J, Nilan R. Rudolph Ulrich and the Stanford Arizona Garden. Sandstone Tile. 2003;27(2):3-

13.

28. Rizzo DM, Garbelotto M. Sudden oak death : endangering California and Oregon forest ecosystems. Front Ecol Env. 2003;1(5):197-204.

29. MacArthur-Waltz D, Lee G, Nelson R, Gu A, Coleman D, Glockner E, et al. Spatial and temporal partitioning and tree preference in California woodland ants [Internet]. Stanford Digital Repository; 2017. Available from: https://purl.stanford.edu/qz365hg2497

30. Talbot M. Population Studies of the Ant, Prenolepis Imparis Say. Ecolgoy. 1943;24(1):31-44.

292 31. Smith MR. The Biology of Tapinoma Sessile Say, An Important House-Infesting Ant. Ann Entomol Soc Am. 1927;(122):307-30.

294 32. Barbani LE. Foraging activity and food preferences of the odorous house ant (Tapinoma sessile Say) (Hymenoptera: Formicidae). Virginia Polytechnic Institute; 2003.

296 33. Hoey-Chamberlain R, Rust MK, Klotz JH. A Review of the Biology, Ecology, and Behavior of 297 Velvety Tree Ants of North America. Sociobiology. 2013;60(1):1-10.

298 34. Feener DH, Matthew OR, Wackford K, Longo J, Benson W, Gilbert L. Geographic variation in resource dominance-discovery in Brazilian ant communities. Ecology. 2008;89(7):1824-36.

300 35. Parr CL, Gibb H. The discovery-dominance trade-off is the exception, rather than the rule. J Anim Ecol. 2012;81(1):233-41. 
Camponotus semitestaceous

\section{Liometopum occidentale}
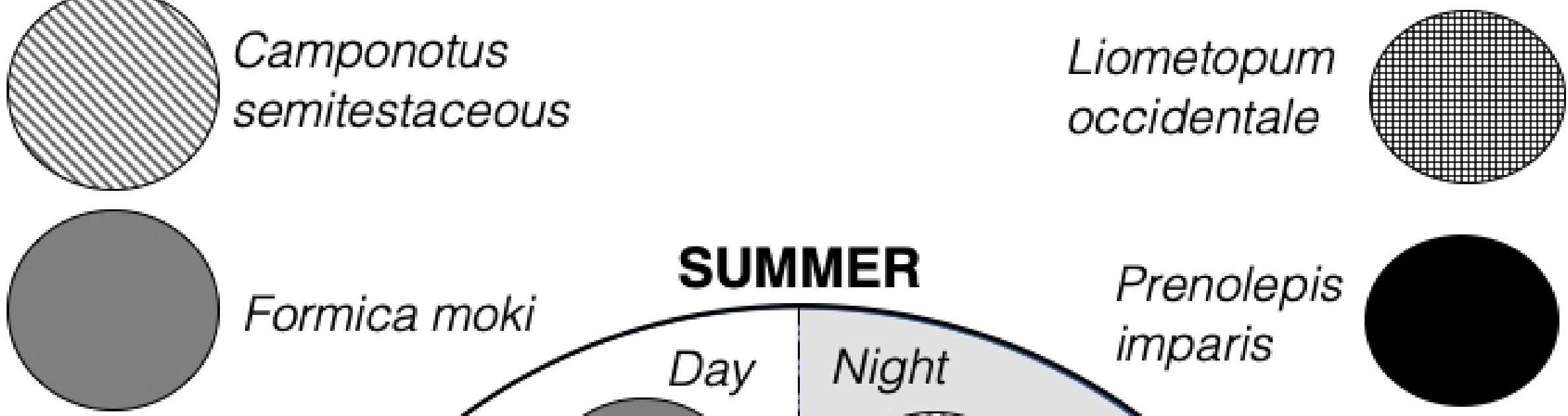

\section{SUMMER}

Formica moki

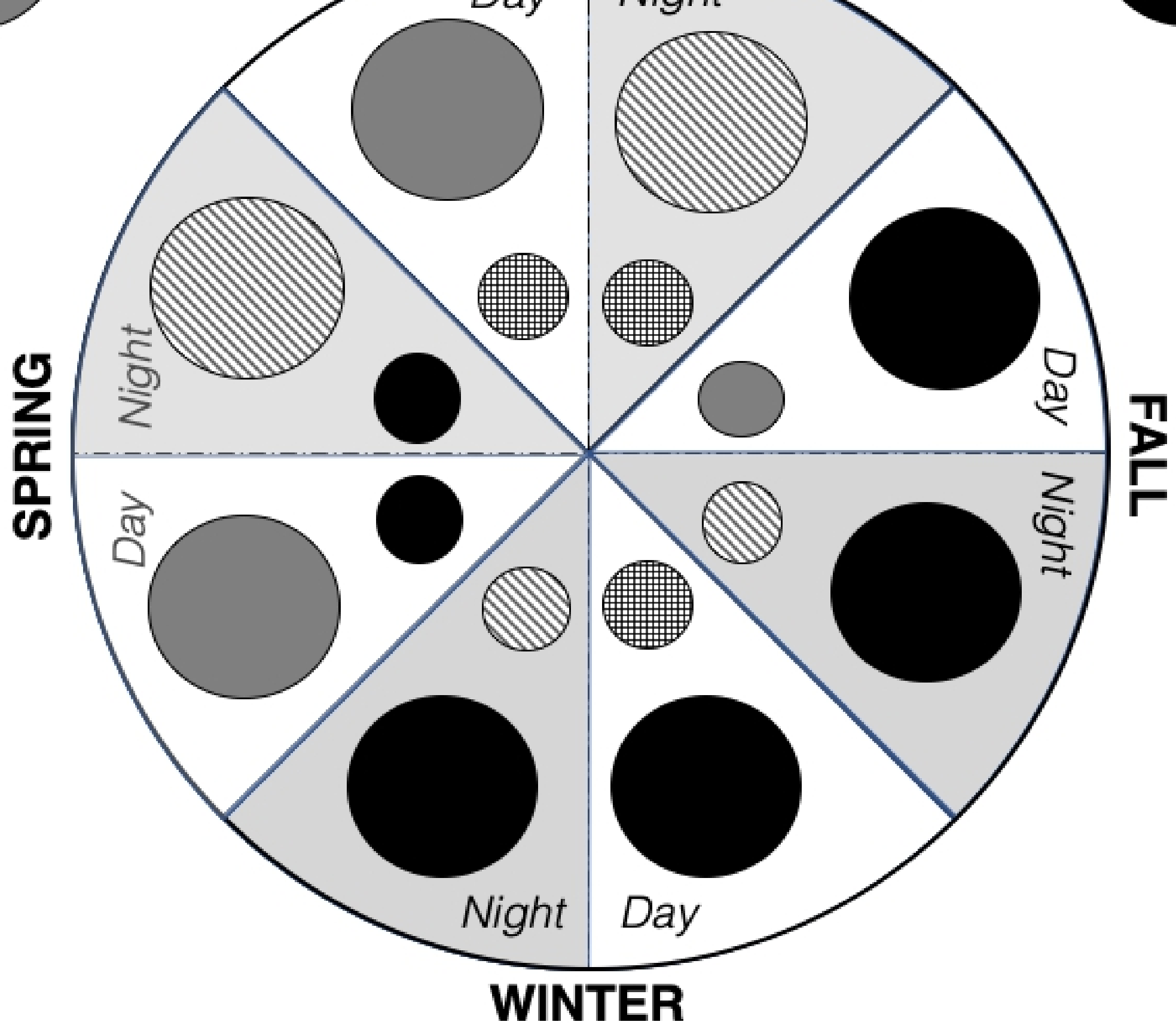

Figure 4 